\title{
Isolated Loco-Regional Recurrence of Breast Cancer - Established and Innovative Therapy Concepts
}

\author{
Isoliertes lokales und lokoregionäres Rezidiv beim Mammakarzinom - \\ bewährte und innovative Therapiekonzepte
}

\author{
Authors \\ E.-M. Grischke ${ }^{1}$, D. Wallwiener ${ }^{1}$, R. Souchon ${ }^{2}$, T. Fehm ${ }^{3}$, C. R. Loehberg ${ }^{4}$, S. M. Jud ${ }^{4}$, M. P. Lux ${ }^{4}$, M. W. Beckmann ${ }^{4}$, \\ S. P. Renner ${ }^{4}$ \\ Affiliations \\ ${ }^{1}$ Dept. of OB/Gyn, University Hospital of Tübingen, Tübingen \\ ${ }^{2}$ Dept. of Radiotherapy, University Hospital of Tübingen, Tübingen \\ ${ }^{3}$ Dept. of OB/Gyn, University Hospital of Düsseldorf, Düsseldorf \\ ${ }^{4}$ Dept. of $\mathrm{OB} /$ Gyn, University Hospital of Erlangen, Erlangen
}

\section{Key words \\ - breast cancer \\ - local recurrence \\ - chemotherapy \\ Schlüsselwörter \\ - Mammakarzinom \\ - Lokalrezidiv \\ - Chemotherapie}

\section{received 11.2.2013 \\ revised 12.3.2013 \\ accepted 13.5.2013}

Bibliography

DOI http://dx.doi.org/

10.1055/s-0032-1328660

Geburtsh Frauenheilk 2013; 73 :

611-622 @ Georg Thieme

Verlag KG Stuttgart · New York . ISSN 0016-5751

\section{Correspondence}

Dr. Christian R. Loehberg, M. D.

University Hospital of Erlangen

Dept. of OB/Gyn

Universitätsstraße 21-23

91054 Erlangen

christian.loehberg@

uk-erlangen.de

\section{Abstract \\ $\nabla$}

The incidence of isolated loco-regional recurrence of breast cancer is between $2-20 \%$. It constitutes the most common type of breast cancer recurrence. In contrast to distant metastasis, a number of curative therapies are available to treat isolated loco-regional recurrence of breast cancer. Screening for early detection and regular examinations as part of a recommended follow-up programme is important. If distant metastasis has been excluded, therapy for recurrence ideally consists of surgery with $\mathrm{R} 0$ resection margins. Radiotherapy is indicated after non-curative surgery (R1/R2) for local tumour control to improve the chances of curative surgery and as a palliative therapy for local control of symptoms in inoperable cancer, also in combination with hyperthermia and systemic therapy. There was previously some uncertainty concerning the benefit of systemic therapy after $\mathrm{R} 0$ resection and breast-conserving therapy and after previous mastectomy. If the recurrence is hormone-receptor positive, (repeat) endocrine systemic therapy is indicated for both constellations. If the hormone-receptor status is negative, the question whether repeat chemotherapy is indicated as an adjuvant therapy and whether it offers a benefit to patients was still controversially discussed. However, data from the CALOR trial presented at the San Antonio Breast Cancer Symposium in 2012 has now answered this question in favour of chemotherapy. These new findings will not merely have an impact on future therapy recommendations but also on the entire clinical management of isolated loco-regional recurrence.

\section{Zusammenfassung \\ $\nabla$}

Das isolierte lokale Rezidiv und das lokoregionäre Rezidiv stellen mit einer Häufigkeit von 2-20\% die häufigsten Manifestationen bei Wiederauftreten eins Mammakarzinoms dar. Im Gegensatz zu einer Fernmetastasierung ist beim isolierten lokalen/lokoregionären Rezidiv des Mammakarzinoms ein kurativer Therapieansatz gegeben. Dieses ist der Grund für den Einsatz von Maßnahmen zur Früherkennung und der Festlegung der entsprechenden Untersuchungen in den empfohlenen Nachsorgeprogrammen. Therapeutisch ist in der Rezidivsituation eine operative Therapie mit einer R0-Resektion anzustreben, wenn eine Fernmetastasierung ausgeschlossen wurde. Indikationen zur Radiotherapie bestehen bei nicht kurativ möglicher operativer Therapie (R1/R2) zur lokalen Tumorkontrolle, zum Erhalt der Aussicht auf eine Kuration und bei Inoperabilität zur lokalen Symptomkontrolle in palliativer Intention, gegebenenfalls in Kombination mit Hyperthermie und systemischer Therapie. Unsicherheit bezüglich des Nutzens systemischer Therapien bestand bislang nach R0-Resektion nach brusterhaltender Therapie oder nach zuvor erfolgter Mastektomie. Bei Hormonrezeptorpositivität des Rezidivs ist bei beiden Konstellationen eine (erneute) endokrine Systemtherapie indiziert. Bei negativem Hormonrezeptorstatus war die Frage offen, inwieweit eine erneute Chemotherapie als adjuvante Maßnahme indiziert ist bzw. einen Benefit für die Patientin ergibt. Mit den Daten der CALORStudie, welche beim San Antonio Breast Cancer Symposium in 2012 vorgestellt wurde, kann diese Frage zugunsten einer Chemotherapie mittlerweile beantwortet werden. Es ist davon auszugehen, dass diese neuen Erkenntnisse nicht nur die weiteren Therapieempfehlungen beeinflussen werden, sondern auch das gesamte klinische Management des alleinigen lokalen bzw. lokoregionären Rezidivs. 


\section{Definition, Incidence and Prognosis for Loco-Regional Recurrence (Adapted from the German inter- disciplinary S3 Guidelines for the Diagnosis, Therapy and Follow-up of Breast Cancer, 2012 [1]) \\ Loco-regional recurrence is defined as: \\ - recurrence of breast cancer in the ipsilateral breast, \\ - at the ipsilateral chest wall including the skin above it, \\ - in the regional axillary lymph nodes, \\ - in the supra- and infraclavicular region, \\ - along the internal mammary vessels.}

Loco-regional recurrence can occur as an isolated cancer or in combination with distant metastasis in other organ systems $[2,3]$. The incidence of local recurrence after breast-conserving surgery and radiotherapy is $5-10 \%$ (after 10 years). The mean 5 -year survival rate is $65 \%(45-79 \%$ ) [4]. Recurrence at the chest wall after mastectomy is reported to occur in $4 \%(2-20 \%)$ of cases (with additional recurrence in the supraclavicular fossa reported to occur in $34 \%[5])$; reported axillary recurrence rates are $1 \%(0.1-8 \%)$ [4, $6]$. The reported 5 -year survival rates for these patients are $50 \%$ (24-78\%) and 55\% (31-77\%), respectively [4]. The reported incidence of loco-regional recurrences occurring simultaneously at different locations is $16 \%(8-19 \%)$; it is associated with a 5 -year survival rate of $21 \%$ (18-23\%) [7] ( $O$ Table 1).

Early detection of isolated loco-regional recurrence positively affects survival [8]. Regular follow-up examinations to confirm that the patient is tumour-free with no local or axillary recurrence are important. As many patients are regularly followed up, the therapy of loco-regional recurrence is predominantly curative (50$70 \%$ ) and only palliative in around $30 \%$ of patients [9-15]. 0 Table 2 lists the risk factors for developing loco-regional recurrence $[8,16-30]$.

The course of disease and biological behaviour do not differ much between in-breast recurrence after breast-conserving therapy (BCT) and local recurrence after modified radical mastectomy (MRM) [25,31-33]. The primary prognostic and predictive factors ( Table 3) such as tumour size [8,34], the presence or absence of multifocal disease [8], localisation [27,34], grading [35], and HER2 and hormone-receptor status [35-38] are also applicable for local recurrence.

It is important to differentiate between "early" $(<2-3$ years) and "late" (>2-3 years) local recurrence. "Early" recurrence is less amenable to curative therapy and is associated with higher rates of further recurrence and distant metastasis $[8,39,40]$.

In individual cases, differentiating loco-regional recurrence from ipsilateral secondary cancer may be difficult [41]. Indications that the lesion may be a secondary cancer requiring the same curative treatment as primary breast cancer include:
Definition, Häufigkeit und Prognose des lokalen/ lokoregionären Rezidivs (adaptiert von der interdisziplinären S3-Leitlinie für die Diagnostik, Therapie und Nachsorge des Mammakarzinoms, 2012 [1]) $\nabla$

Als lokale bzw. lokoregionäre Rezidive werden bezeichnet:

- das Wiederauftreten des Mammakarzinoms in der ipsilateralen Brust,

- an der ipsilateralen Thoraxwand inklusive der darüber liegenden Haut,

- der regionalen Lymphknoten der Axilla,

- der Supra- und Infraklavikularregion,

- und entlang der Mammaria-interna-Gefäße.

Das lokale bzw. lokoregionäre Rezidiv kann isoliert oder in Kombination mit Fernmetastasen in anderen Organsystemen vorliegen [2,3]. Lokalrezidive nach brusterhaltender Operation und Bestrahlung treten mit einer Häufigkeit von 5-10\% (nach 10 Jahren) auf. Die mediane 5-Jahres-Überlebensrate beträgt 65\% (45-79\%) [4]. Rezidive an der Thoraxwand nach Mastektomie werden in 4\% (2-20\%) (zusätzlich in der Supraklavikulargrube in 34\% [5]) und Rezidive in der Axilla in 1\% $(0,1-8 \%)$ beobachtet $[4,6]$. Diese Patientinnen weisen ein 5-JahresÜberleben von 50\% (24-78\%) bzw. 55\% (31-77\%) auf [4]. An verschiedenen Stellen gleichzeitig auftretende lokale oder lokoregionale Rezidive werden mit einer Häufigkeit von 16\% (8-19\%) beobachtet und sind mit einem 5-Jahres-Überleben von 21\% (18-23\%) verbunden [7] (๑ Tab. 1).

Die Früherkennung des isolierten lokalen bzw. lokoregionären Rezidivs hat einen positiven Einfluss auf das Überleben [8]. Damit ist die regelmäßige Überprüfung der lokalen und axillären Tumorfreiheit eine wichtige Aufgabe der Nachsorge. Dementsprechend werden lokale/lokoregionäre Rezidive überwiegend mit kurativer (50-70\%) und lediglich bei ca. 30\% mit palliativer Zielsetzung therapiert [9-15], zu den Risikofaktoren der Entstehung eines lokalen/lokoregionären Rezidivs siehe Tab. $2[8,16-30]$.

Der Verlauf und das biologische Verhalten des In-Brust-Rezidivs nach brusterhaltender Therapie (BET) und des Lokalrezidivs nach modifiziert radikaler Mastektomie (MRM) unterscheiden sich nicht wesentlich [25,31-33]. Beim Auftreten eines lokalen Rezidivs gelten weiterhin die primären Prognose- bzw. Prädiktivfaktoren ( $\odot$ Tab. 3), wie Tumorgröße [8,34], Multifokalität [8], Lokalisation [27,34], Grading [35] und HER2- bzw. Hormonrezeptorstatus [35-38].

Unterschiede bestehen zwischen „frühen“ ( $<2-3$ Jahre) und „späten“ (>2-3 Jahre) Lokalrezidiven. Die „frühen“ Rezidive können in einem geringeren Maße geheilt werden und sind auch mit einer höheren Zweitrezidiv- und Fernmetastasierungsrate korreliert [8,39,40]. Im Einzelfall kann die Abgrenzung eines lokalen/lokoregionären Rezidivs von einem ipsilateralen Zweitkarzinom schwierig sein [41]:

Table 1 Incidence of and prognosis for loco-regional recurrence in patients with breast cancer (adapted from the AGO [Arbeitsgemeinschaft Gynäkologische Onkologie e. V.] Breast Guidelines Version 2013.1D).

\begin{tabular}{|c|c|c|}
\hline Localisation & Incidence (\%) & Overall 5-year survival (\%) \\
\hline Ipsilateral in-breast recurrence (post BCT + radiotherapy) & $10(2-20)$ & $65(45-79)$ \\
\hline Chest wall (post mastectomy) & $4(2-20)$ & $50(24-78)$ \\
\hline Additionally present in the supraclavicular fossa & 34 & 49 (3-y. OS) \\
\hline \multicolumn{3}{|l|}{ Axilla: } \\
\hline - after axillary dissection & $1(0.1-8)$ & $55(31-77)$ \\
\hline after SNB & 1 & 93 \\
\hline Multiple localisations & $16(8-19)$ & $21(18-23)$ \\
\hline
\end{tabular}


Table 2 Risk factors for developing loco-regional recurrence after modified radical mastectomy (MRM) or breast-conserving therapy (BCT) (adapted from the AGO Breast Guidelines Version 2013.1D).

Young age
Positive microscopic margins
Omission of radiotherapy (if indicated as adjuvant therapy)
Extensive intraductal component
Vascular invasion
Triple negative and HER2+/HR-negative vs. HR-positive
Grading (G3 vs. G1)
Elevated proliferation markers (e.g. Ki67)
PT (>2 vs. $\leq 2 \mathrm{~cm}$ )
PN (N1 vs. N0)
Number of affected lymph nodes
Medial tumour location (vs. central/lateral)

- long period of time has elapsed since primary cancer

- different localisation in the breast

- different tumour biology (hormone-receptor status, HER2 status, grading).

Initially, the treatment of loco-regional recurrence is local. In women with operable cancer, the goal is to achieve complete resection of the recurrence (i.e. with histologically tumour-free margins). Postoperative radiotherapy after excision can improve local tumour control [42].

Radiation therapy is the therapy of choice to treat inoperable cancer with no distant metastasis [42]. Because of the high risk of subsequent systemic progression, systemic therapy may also be considered in addition to local treatment of the recurrence (surgery and/or radiotherapy) $[43,44]$. However, the impact of systemic chemotherapy on these types of cancer has not yet been confirmed in prospective randomised studies [38,44-47].

\section{Surgical Therapy for Loco-Regional Recurrence of Breast Cancer (Adapted from the interdisciplinary S3 Guidelines for the Diagnosis, Therapy and Follow-up of Breast Cancer, 2012 [1])}

In contrast to distant metastasis, treatment of clinically confirmed single loco-regional recurrence can be curative, but this requires an individualised approach.

The treatment of local recurrence consists of surgical resection. Mastectomy achieves the best tumour control [25]. Repeat breast-conserving surgery is a viable option in favourable circumstances such as DCIS, invasive carcinoma after a long recurrence-free period, no cancer affecting the skin or if the cancer is at a considerable distance from the location of the primary tumour $[48,49]$.

The incidence of loco-regional recurrence after mastectomy is reported to be $2-20 \%$ [4]. Of these cases, around one third of cancers manifest only as loco-regional recurrence, followed by - in order of decreasing frequency - cancers of the chest wall, the supraclavicular region, axillary cancers and multilocal occurrence in $10-30 \%$ of cases [ $50-52]$.
Table 3 Prognostic and predictive factors for loco-regional recurrence after MRM or BCT (adapted from the AGO Breast Guidelines Version 2013.1D).

Risk factors for further recurrence:
tumour size
- multifocal disease
Risk factisation
- early (<2-3 years) vs. late recurrence
hemangiosis and/or lymphangiosis carcinomatosa/grading/ER-negative/
narrow resection margins (if $>2$ factors positive)
Predictive factors for therapy:
- HER2 status
- ER/PR status

Für ein Zweitkarzinom, das wie ein primäres Mammakarzinom kurativ zu behandeln ist, sprechen:

- langes zeitliches Intervall zum Erstkarzinom

- unterschiedliche Lokalisation in der Mamma

- unterschiedliche Tumorbiologie (Hormonrezeptor-, HER2-Status, Grading).

Ein Lokalrezidiv bzw. ein lokoregionäres Rezidiv wird meist zunächst lokal therapiert. Bei operablen Fällen ist eine komplette Exzision des Rezidivtumors anzustreben (d.h. histologisch freie Ränder). Eine postoperative Radiotherapie nach Exstirpation kann die lokale Tumorkontrolle verbessern [42].

Bei Inoperabilität ohne Vorliegen von Fernmetastasen ist die Radiotherapie das Therapieverfahren der Wahl [42]. Aufgrund des hohen Risikos für eine nachfolgende systemische Progression kann neben der lokalen Therapie des Rezidivs (Operation und/oder Radiotherapie) eine systemische Therapie zusätzlich erwogen werden $[43,44]$. Der Effekt einer systemischen Chemotherapie war hierbei allerdings bisher noch nicht durch prospektive randomisierte Studien belegt $[38,44-47]$.

\section{Operative Therapieansätze beim lokal/lokoregionären Rezidiv eines Mammakarzinoms (adaptiert von der interdisziplinären S3-Leitlinie für die Diagnostik, The- rapie und Nachsorge des Mammakarzinoms, 2012 [1]) $\nabla$}

Im Vergleich zu einer Fernmetastasierung besteht bei einem klinisch nachgewiesenen alleinigen lokalen/lokoregionären Rezidiv ein kurativer Ansatz, welcher ein individualisiertes Vorgehen erfordert.

Die Therapie von Lokalrezidiven besteht in der operativen Entfernung. Die höchste Tumorkontrolle wird hierbei durch die Mastektomie erzielt [25]. Ein erneutes brusterhaltendes Vorgehen kann bei günstiger Ausgangsposition - DCIS oder invasives Karzinom mit langem rezidivfreiem Intervall oder bei fehlendem Hautbefall bzw. groBem Abstand zur primären Tumorlokalisation - erfolgen [48,49]. Die Inzidenz von lokalen/lokoregionären Rezidiven nach Mastektomie beträgt 2-20\% [4]. Unter diesen ist bei etwa einem Drittel der Rückfall lokoregionär begrenzt und - in absteigender Häufigkeit - an der Thoraxwand, in der Supraklavikularregion, in der Axilla sowie in $10-30 \%$ multilokal manifestiert [50-52]. 
Importance of Histological Testing with Biopsy of Tumour Tissue for Repeat Determination of Prognostic Parameters in Loco-Regional Recurrence of Breast Cancer

$\nabla$

Histopathological work-up is the first step if there is a clinical suspicion of loco-regional recurrence, as it is also necessary to determine biologically relevant factors affecting prognosis, such as levels of the proliferation marker Ki-67, hormone receptor status and HER2/neu status [21,53-55].

These factors may differ in loco-regional recurrence of breast cancer compared to the primary tumour [56]. In an overview [56] of 8 studies [57-64] investigating hormone receptor and HER2 status in loco-regional recurrence, significant differences were found between the primary tumour and the recurrence (oestrogen receptor [ER]: 5.5-38.1\%; progesterone receptor [PR]: 11.8-34.9\%; and HER2 status: 1.1-16.7\%) with a mean value of $19.8 \%$ (median $=13.4 \%$; $n=271$ ) for ER, $27.1 \%$ (median $=28.6 \% ; n=242)$ for PR, and $6.6 \%($ median $=1.6 \% ; n=177)$ for HER2 ( Table 4).

These differences could have been caused by postoperative adjuvant therapies such as radiation therapy, chemotherapy or endocrine therapy. In the study with the lowest differences in hormone receptor status, a cut-off of $1 \%$ for ER/PR expression was selected [57]. This corresponds to current recommendations [54] and will lead, by definition, in there being more hormone receptor-positive breast cancers in future. It could also result in a decrease in differences with regard to the assessment of hormone receptor status between the primary tumour and the recurrence as, despite the clear decrease in hormone receptor expression in the recurrence (decreases in expression are more common), recurrences can still be classified as hormone receptor-positive. With the exception of the findings reported by Guarneri et al. [59] (16.7\%), the differences with regard to HER2 status between the primary tumour and the recurrence were minimal (1.1$2.0 \%)$.

\section{Importance of Differentiating between Loco-Regional Recurrence and Secondary Cancer}

In individual cases, it may be difficult to differentiate loco-regional recurrence from ipsilateral secondary cancer [41]. While it is assumed that local recurrences originate from residual tumour cells, ipsilateral secondary cancers appear to be de novo breast cancers independently occurring in the same breast. This would mean that the tumour biology of this secondary cancer also differs from that of the primary tumour [65].
Bedeutung der histologischen Sicherung und Entnahme von Tumorgewebe zur erneuten Bestimmung der Prognoseparameter beim lokalen/lokoregionären Rezidivs des Mammakarzinoms

$\nabla$

Bei klinischem Verdacht eines lokalen/lokoregionären Rezidivs muss zunächst eine histopathologische Abklärung erfolgen, u.a. auch zur Bestimmung prognoserelevanter biologischer Eigenschaften des Tumors, wie z. B. des Proliferationsmarkers Ki-67, des Hormonrezeptorstatus oder des HER2-Status [21,53-55].

Bei lokalen/lokoregionären Rezidiven des Mammakarzinoms können sich die Faktoren im Vergleich zum Primärtumor wandeln [56]. In einer Übersicht [56] von 8 Studien [57-64] die den Hormonrezeptorund HER2-Status beim lokalen/lokoregionären Rezidiv untersucht haben, zeigten sich deutliche Unterschiede zwischen dem Primärtumor und dem Rezidiv (5,5-38,1\% für den Östrogenrezeptor [ER], 11,8-34,9\% für den Progesteronrezeptor [PR], und 1,1-16,7\% für den HER2-Status) mit einem durchschnittlichen Wert von 19,8\% (median = 13,4\%; $n=271$ ) für ER, 27,1\% (median = 28,6\%; $n=242$ ) für $P R$, und $6,6 \%$ (median $=1,6 \% ; n=177$ ) für HER2 ( $\odot$ Tab. 4 ).

Derartige Unterschiede könnten möglicherweise durch die postoperativen, adjuvanten Therapieformen wie Radiotherapie, Chemotherapie oder endokrine Therapie verursacht worden sein. In der Studie mit den geringsten Unterschieden des Hormonrezeptorstatus war ein Cut-off-Limit von 1\% für die ER/PR-Expression gewählt worden [57]. Dieses entspricht den aktuellen Empfehlungen [54], welches in der Folge dazu führt, dass es per Definition zukünftig mehr hormonrezeptorpositive Mammakarzinome geben wird. Dieses könnte auch zu geringeren Unterschieden bezüglich der Beurteilung des Hormonrezeptorstatus zwischem dem Primärtumor und einem Rezidiv führen, da ein Rezidiv trotz einer deutlichen Reduktion der Hormonrezeptorexpression (eine Reduktion ist der häufigere Fall) sehr wohl noch als hormonrezeptorpositiv gewertet wird. Mit Ausnahme der Untersuchung von Guarneri et al. [59] (16,7\%) waren die Unterschiede bezüglich des HER2-Status zwischen Primärtumor und Rezidiv minimal $(1,1-2,0 \%)$.

\section{Bedeutung der Unterscheidung eines lokalen/ lokoregionären Rezidivs von einem Zweitkarzinom $\nabla$}

Im Einzelfall kann die Abgrenzung eines lokalen/lokoregionären Rezidivs von einem ipsilateralen Zweitkarzinom schwierig sein [41]. Während angenommen wird, dass ein Lokalrezidiv von verbliebenen Tumorzellen ausgeht, scheinen ipsilaterale Zweitkarzinome De-novoMammakarzinome in der gleichen Brust zu sein. Dies würde bedeuten dass sich dieses Zweitkarzinom auch in seiner Tumorbiologie von dem Primärtumor unterscheidet [65].

Table 4 Differences in ER, PR and HER2 expression between the primary tumour and loco-regional recurrence (modification based on [56]).

\begin{tabular}{|c|c|c|c|c|}
\hline Method & Difference in ER expression & Difference in PR expression & Difference in HER2 expression & References \\
\hline $\mathrm{IHC/CISH}$ & $4 / 50(8.0 \%)$ & $16 / 50(32.0 \%)$ & $0 / 48(0 \%)$ & [57] \\
\hline $\mathrm{IHC} / \mathrm{FISH}$ & - & - & $5 / 30(16.7 \%)$ & [59] \\
\hline IHC/EIA & $4 / 14(28.6 \%)$ & $4 / 14(28.6 \%)$ & $0 / 14(0 \%)$ & {$[64]$} \\
\hline $\mathrm{IHC}$ & $6 / 45(13.0 \%)$ & $16 / 45(42.0 \%)$ & $1 / 45(2.0 \%)$ & {$[61]$} \\
\hline $\mathrm{IHC}$ & $24 / 63(38.1 \%)$ & $22 / 63(34.9 \%)$ & - & {$[62]$} \\
\hline $\mathrm{IHC}$ & $9 / 279(3.2 \%)$ & - & - & {$[58]$} \\
\hline DCA & $7 / 48(15.0 \%)$ & - & - & {$[60]$} \\
\hline DCA & $4 / 29(13.8 \%)$ & - & - & {$[63]$} \\
\hline
\end{tabular}

IHC = immunohistochemistry, FISH/CISH = fluorescent/chromogenic in situ hybridization, DCA = dextran-coated charcoal assay 
In many clinical studies investigating breast-conserving surgery to treat breast cancer, around $80 \%$ of local recurrences were found near the site of the former primary tumour [66-68]. The findings of studies which attempted to differentiate between local recurrence and ipsilateral secondary cancer are often conflicting, but overall they report fewer cases of "true" local recurrences (50-70\%) and more ipsilateral secondary cancers [20,40,41,49, 69-72]. A possible explanation for this heterogeneous data could be differences in the criteria used to define local recurrence and ipsilateral secondary cancer $[20,40,41,49,69-72]$. Most studies use the following criteria to differentiate between local recurrence and ipsilateral secondary cancer: histological type, grading, hormone receptor status and localisation. However, some studies also include parameters such as resection margins and cytological factors obtained from flow cytometry analysis (fluorescenceactivated cell sorting, FACS) (summarised in [41]).

In most studies, the mean time to developing local recurrence was found to be shorter than the mean time to developing ipsilateral secondary cancer, and the overall prognosis for patients with loco-regional recurrence was reported to be poorer compared to patients with ipsilateral secondary cancer (summarised in [41]). However, it must be admitted that the use of differing criteria, as mentioned above, could be the cause of this heterogeneous data; more pathological and biomolecular investigations are needed to clarify these points [73].

It is important to differentiate between ipsilateral loco-regional recurrence and ipsilateral secondary cancer on the one hand and contralateral secondary cancer and cervical lymph node metastases and lymph node metastases of the contralateral internal mammary artery on the other.

Around $2-20 \%$ of patients with breast cancer go on to develop contralateral secondary cancer (synchronous secondary primary cancer: shorter time to development; metachronous secondary primary cancer: longer time to development) [74,75]; however there are still no standard definitions in the literature or in treatment recommendations. After a diagnosis of primary breast cancer, the annual risk for secondary primary cancer is $0.7-1.8 \%$, while the risk for patients with BRCA $1 / 2$ mutations is $18-40 \%$ $[76,77]$.

It is still unclear whether the prognosis is better for patients with loco-regional recurrence or for patients with contralateral secondary cancer. Recent studies have reported both better and poorer prognoses for contralateral secondary primary cancer compared to ipsilateral local recurrence $[74,78,79]$.

Prognostic factors associated with contralateral secondary cancer include age, the period of time elapsed between cancer development, how the secondary cancer was detected, the adjuvant therapy used to treat the primary cancer, hormone receptor status (patients with hormone receptor-negative primary tumour have a 10-fold increased risk of developing a secondary hormone receptor-negative tumour) and the presence or absence of BRCA 1 / 2 mutation [74-76, 80, 81].

It is also unclear whether the contralateral secondary cancer should be treated like a new primary tumour (two individual cancers) and to what extent there is a biological link between the primary and the secondary cancer $[20,74]$.

As the biological properties of the recurrence or the secondary cancer but also of the primary tumour have a big impact on both prognosis and the choice of treatment, several recent studies have looked at different approaches to determine the precise pathobiology and pathogenesis of secondary cancers [75, 82]. While some studies use standard immunohistochemical parame-
In vielen klinischen Studien, die sich mit der brusterhaltenden Operation beim Mammakarzinom beschäftigten, zeigten sich die Lokalrezidive in ca. 80\% im Bereich des ehemaligen Primärtumors [66-68]. In Studien, in denen versucht wurde, zwischen einem Lokalrezidiv und einem ipsilateralen Zweitkarzinom zu unterscheiden, zeigten sich widersprüchliche Ergebnisse mit aber insgesamt weniger „echten“ Lokalrezidiven (50-70\%) und mehr ipsilateralen Zweitkarzinomen [20,40,41,49,69-72]. Eine mögliche Erklärung für die heterogene Datenlage sind die unterschiedlich angewandten Kriterien zur Definition eines Lokalrezidivs bzw. eines ipsilateralen Zweitkarzinoms [20, $40,41,49,69-72]$. In den meisten Studien wurden die folgenden Kriterien zur Unterscheidung eines Lokalrezidivs vom ipsilateralen Zweitkarzinom verwandt: histologischer Typ, Grading, Hormonrezeptorstatus und Lokalisation. Allerdings wurden in manchen Studien auch Parameter wie Resektionsränder und zellbiologische Faktoren aus Durchflusszytometrie-Analysen (FACS) einbezogen (zusammengefasst in [41]).

In den meisten Studien war das Zeitintervall bis zur Entstehung eines Lokalrezidivs kürzer als bis zur Entstehung eines ipsilateralen Zweitkarzinoms und die Prognose für Patientinnen mit einem lokalen/lokoregionären Rezidiv war insgesamt schlechter als bei Patientinnen mit einem ipsilateralem Zweitkarzinom (zusammengefasst in [41]). Eingeräumt werden muss hier allerdings, dass die oben genannten unterschiedlichen Kriterien für eine heterogene Datenlage gesorgt haben könnten und hier weitere pathologische und molekularbiologische Untersuchungen Klarheit schaffen müssen [73].

Von einem ipsilateralen lokalen bzw. lokoregionären Rezidiv bzw. ipsilateralen Zweitkarzinom sind die kontralateralen Zweitkarzinome sowie zervikale Lymphknotenmetastasen und Lymphknotenmetastasen der kontralateralen A. mammaria interna abzugrenzen.

2-20\% der Patientinnen mit einem Mammakarzinom entwickeln ein kontralaterales Zweitkarzinom (synchrones Zweitkarzinom - kurzes Zeitintervall; metachrones Zweitkarzinom - längeres Zeitintervall) $[74,75]$, allerdings gibt es sowohl in der Literatur als auch in den Therapieempfehlungen keine einheitlichen Definitionen. Nach Erstdiagnose eines Mammakarzinoms beträgt das Zweitkarzinomrisiko pro Jahr 0,7-1,8\%, und bei BRCA-1/2-Mutationsträgerinnen liegt das Risiko bei $18-40 \%[76,77]$.

Eine offene Frage ist, ob eine Patientin mit einem lokalen/lokoregionären Rezidiv oder eine Patientin mit einem kontralateralem Zweitkarzinom eine bessere Prognose aufweist. Aktuelle Studien konnten für das kontralaterale Zweitkarzinom im Vergleich zum ipsilateralen Lokalrezidiv sowohl eine bessere als auch schlechtere Prognose [74, $78,79]$ zeigen.

Mit einem kontralateralen Zweitkarzinom assoziierte Prognosefaktoren sind Alter, Zeitintervall zwischen beiden Karzinomen, Art und Weise der Detektion des Zweitkarzinoms, adjuvante Therapie des ersten Karzinoms, Hormonrezeptorstatus (bei hormonrezeptornegativem Primärtumor 10-fach erhöhtes Risiko für die Entwicklung eines sekundär hormonrezeptornegativen Tumors) und BRCA-1/2-Mutation $[74-76,80,81]$.

Unklar ist auch, ob das kontralaterale Zweitkarzinom wie ein neuer Primärtumor behandelt ( 2 individuelle Karzinome) werden soll und inwieweit eine biologische Beziehung zwischen 1. und 2. Karzinom besteht $[20,74]$.

Da die biologischen Eigenschaften des Rezidivs bzw. des Zweitkarzinoms, aber auch die des Primärtumors großen Einfluss sowohl auf die Prognose als auch auf die Therapiewahl haben, beschäftigen sich aktuelle Studien mit verschiedenen Ansätzen zur genaueren pathobiologischen Differenzierung bzw. der Pathogenese von Zweitkarzinomen [75, 82]. Neben den bekannten immunhistochemischen Parametern stellt der HUMARA Clonality Assay einen modernen Ansatz 
ters, the HUMARA clonality assay represents a modern approach to investigating whether two tumours are derived from the same progenitor cells. The assay uses PCR amplification of X-linked genes and examines $\mathrm{X}$-chromosome inactivation patterns in the tumours of female patients to analyse the clonality of tumours [75].

\section{Importance of Indications for Systemic Therapy to Treat Loco-Regional Recurrence of Breast Cancer \\ $\nabla$}

The benefit of endocrine systemic therapy as an adjuvant treatment for both pre-menopausal and post-menopausal women with hormone receptor-positive recurrence has been demonstrated in many studies $[1,43,83,84]$.

In contrast, there are currently no good data from controlled clinical trials on the survival benefits of adjuvant chemotherapy for recurrence. For this reason, neither the current version of the ESMO (European Society for Medical Oncology) Guideline [53], nor the NCCN (National Comprehensive Cancer Network) Guideline [85] nor the German S3 Guidelines [1] include any clear recommendations for chemotherapy to treat recurrence. This also applies to women with recurrence in the chest wall after mastectomy or with ipsilateral axillary recurrence $[38,45,86,87]$. Systemic therapy is currently only indicated to reduce the size of the recurrence if $\mathrm{R} 0$ resection would otherwise not be possible or if the tumour would otherwise be inoperable. $[38,45,86-88]$ ( Table 5).

The benefits of antineoplastic systemic therapy after R0 resection in patients with hormone receptor-negative recurrence and no clinical or imaging evidence of distant metastasis are still being discussed. The results of the CALOR trial (Chemotherapy as Adjuvant for LOcally Recurrent breast cancer) presented by Aebi et al. at the San Antonio Breast Cancer Symposium in December 2012 include new data which may lead to changes in current therapeutic approaches [89]. The CALOR trial was the result of a co-operation between the Breast International Group (BIG) and the American NSABP (National Surgical Adjuvant Breast and Bowel Project) study group.

In the study, a total of 162 patients who had repeat breast-conserving therapy for in-breast recurrence or surgery for chest wall recurrence were randomised into one of two groups. Randomisation was either into a control arm or into a chemotherapy arm. Patients with loco-regional recurrence additionally received endocrine therapy. If the recurrence was HER2-positive, the patient had the additional option of receiving HER2-targeted therapy. The chemotherapy regimen was at the discretion of the treating physicians and depended on the prior adjuvant chemotherapy administered. The requirement was the administration of at least 2 drugs (cytostatic drugs) over a treatment period of 3-6 months. Over $50 \%$ of loco-regional recurrences are in-breast recurrences and over $30 \%$ are chest wall recurrences. $13 \%$ of patients included in the study had metastatic spread into regional lymph nodes.

The results showed a benefit for the group of patients treated with adjuvant chemotherapy. Disease-free survival (DFS) in the chemotherapy group after 5 years was $69 \%$ compared to $57 \%$ for the control group (HR 0.59; 95\% CI 0.35-0.99; $\mathrm{p}=0.046$ ), and 5year overall survival was $88 \%$ for the chemotherapy group compared to $76 \%$ for the controls (HR 0.41 ; 95\% CI 0.19-0.89; $\mathrm{p}=0.02$ ) ( Fig. 1). Multivariate analysis showed that chemotherapy remained a significant prognostic factor for both disease-free and overall survival. dar, um zu prüfen ob 2 Tumoren aus den gleichen Vorläuferzellen (progenitor cells) entstanden sind. Dies ist eine Klonalitätsanalyse mittels PCR-Amplifikation X-chromosomal gebundener Gene, eine Methode zur Analyse der Klonalität von Tumoren, die in der Untersuchung des Inaktivierungsmusters von X-Chromosomen-gekoppelten Genloci bei Tumoren weiblicher Patienten besteht [75].

\section{Bedeutung und Indikation zur systemischen Therapie des lokalen/lokoregionären Rezidivs beim Mamma- karzinom}

Die endokrine systemische Therapie stellt sowohl in der Prä- als auch in der Postmenopause eine auf hohem Evidenzniveau abgesicherte Indikation bei Patientinnen mit einem hormonrezeptorpositiven Rezidivtumor dar [1,43, 83, 84].

Für die Indikationsstellung zur Chemotherapie existierten bislang keine ausreichend validen Daten aus klinischen kontrollierten Studien, sodass weder in der aktuellen Fassung der ESMO (European Society for Medical Oncology)-Guideline [53], der NCCN (National Comprehensive Cancer Network)-Guideline [85] noch der deutschen S3Leitlinie [1] diesbezüglich eine eindeutige Empfehlung ausgesprochen worden ist. Das Gleiche galt für Patientinnen mit einem Thoraxwandrezidiv nach Mastektomie oder auch im Falle eines ipsilateralen axillären Rezidivs [38,45, 86, 87]. Eine Systemtherapie war lediglich zur Verkleinerung einer prinzipiell operablen Rezidivmanifestation indiziert, wenn primär ein R0-Status nicht sicher erreicht werden konnte bzw. wenn die Operabilität nicht gegeben war [38,45, 86-88] (๑Tab. 5).

Zur Diskussion führt die Frage zum Einsatz einer antineoplastischen systemischen Therapie nach erreichter R0-Resektion bei klinischem bzw. in der Bildgebung fehlendem Fernmetastasennachweis insbesondere bei Patientinnen mit einem hormonrezeptornegativen Rezidiv. Einen neuen Aspekt mit möglicherweise resultierender Änderung des bisherigen therapeutischen Vorgehens präsentierte die CALOR-Studie (Chemotherapy as Adjuvant for LOcally Recurrent breast cancer), die von Aebi et al. beim San Antonio Breast Cancer Symposium im Dezember 2012 vorgestellt wurde [89]. Die CALORStudie war eine Kooperation zwischen der Breast International Group (BIG) mit der US-amerikanischen NSABP (National Surgical Adjuvant Breast and Bowel Project)-Studiengruppe.

Im Rahmen der Studie wurden insgesamt 162 Patientinnen nach erneuter brusterhaltender Therapie sowohl aufgrund eines In-BrustRezidivs als auch nach operativer Therapie eines Thoraxwandrezidivs randomisiert. Die Randomisation erfolgte entweder in einen Beobachtungsarm oder in einen Arm mit nachfolgender Chemotherapie. Dabei erhielten Patientinnen mit einem hormonrezeptorpositiven lo-

Table 5 Indications for systemic therapy in patients with loco-regional recurrence of breast cancer.

Tumour downstaging to achieve/optimise operability
After curative R0 resection
not amenable to radiotherapy
In patients with concomitant visceral and/or ossary metastases
Where possible, after histological determination of hormone receptor
and HER2 status
if the tumour is ER/PR-positive: endocrine therapy
if the tumour is HER2-positive: trastuzumab in combination
with chemotherapy




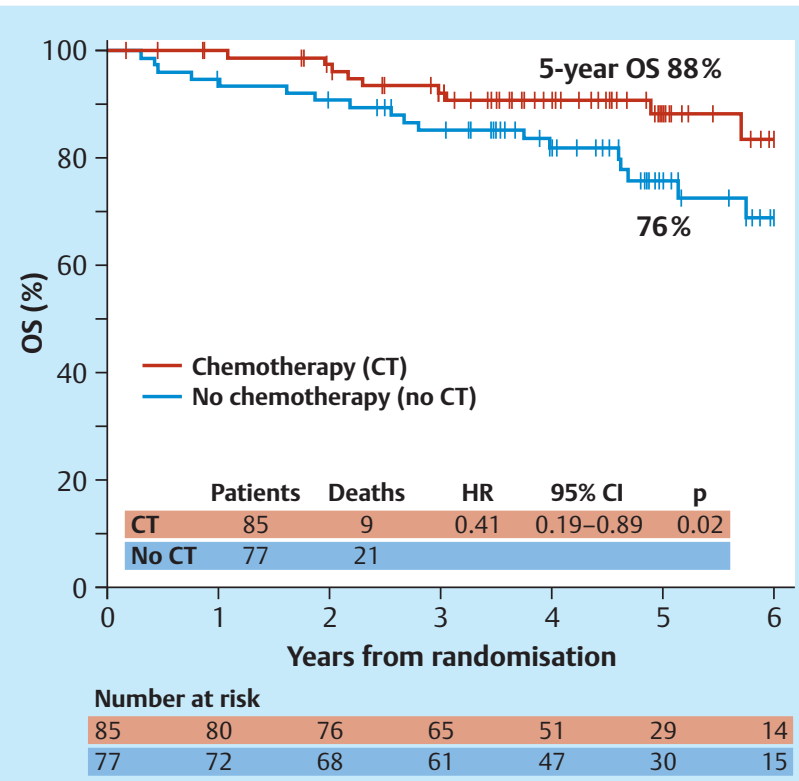

Fig. 1 Overall survival in the CALOR trial [89]. The CALOR (Chemotherapy as Adjuvant for LOcally Recurrent breast cancer) trial demonstrated a survival benefit of $12 \%$ for patients with loco-regional recurrence of breast cancer treated with chemotherapy. Adjuvant chemotherapy was particularly effective for the group of patients with hormone receptor-negative breast cancer.

The benefit of adjuvant chemotherapy was most significant for patients with hormone receptor-negative loco-regional recurrence: after 5 years, $67 \%$ were still disease-free compared to $35 \%$ who had not received additional chemotherapy (HR 0.32; 95\% CI $0.14-0.73 ; p=0.007$ ). This significant benefit was not found for patients with hormone receptor-positive breast cancer (DFS: 70 vs. $69 \%$, HR 0.94, p=0.87; overall survival). The 5-year overall survival rate for patients with hormone receptor-negative locoregional recurrence was $79 \%$ for patients who received adjuvant chemotherapy compared to $69 \%$ for controls (HR 0.43; $95 \% \mathrm{CI}$ $0.15-1.24 ; p=0.12$ ). In the hormone receptor-positive cohort, the difference in 5-year overall survival was 94\% compared to $80 \%$, although this figure was not statistically significant (HR $0.40,95 \%$ CI $0.12-1.28 ; p=0.12$ ). The lack of statistical significance in the subgroups with regard to overall survival can be explained by the small size of the cohorts.

It is safe to assume that these new findings will not only have an impact on future therapy recommendations but also for practical clinical management.

It is recommended that patients with resectable tumours, positive HER2 status and no previous trastuzumab therapy should receive trastuzumab, although this recommendation has only been extrapolated from findings and studies of patients with metastatic disease $[1,53]$. This recommendation needs to be modified for patients who previously received trastuzumab as adjuvant therapy. New targeted therapies such as pertuzumab could be of interest here. Both trastuzumab therapy and chemotherapy are clearly indicated in patients with advanced non-resectable tumours. kalen/lokoregionären Rezidiv zusätzlich eine endokrine Therapie. Im Falle eines positiven HER2-Status des Rezidivtumors war eine HER2gerichtete Therapie optional. Das Chemotherapieregime konnte in Abhängigkeit von der Vorbehandlung durch die jeweiligen therapierenden Ärztinnen und Ärzte ausgewählt werden. Voraussetzung war, dass jeweils mindestens 2 Therapeutika (Zytostatika) über einen Behandlungszeitraum von 3-6 Monaten eingesetzt wurden. In über $50 \%$ der lokalen/lokoregionären Rezidive handelte es sich dabei um ein In-Brust-Rezidiv, in knapp über 30\% um ein Thoraxwandrezidiv. Einen metastatischen Befall der regionären Lymphknoten zeigten $13 \%$ der Patientinnen, die in die Studie eingeschlossen wurden.

Die Ergebnisse präsentieren für das Gesamtkollektiv Vorteile zugunsten der chemotherapeutisch behandelten Patientinnen: Nach 5 Jahren waren noch 69 vs. 57\% krankheitsfrei (HR 0,59; 95\%-KI 0,35$0,99 ; \mathrm{p}=0,046)$. Das 5-Jahres-Gesamtüberleben betrug 88 vs. $76 \%$ (HR 0,41; 95\%-KI 0,19-0,89; p =0,02) ( A Abb. 1). In der multivariaten Analyse zum krankheitsfreien und Gesamtüberleben blieb die Chemotherapie jeweils signifikanter prognostischer Faktor.

Besonders deutlich profitierten Patientinnen mit einem hormonrezeptornegativen lokalen/lokoregionären Rezidiv von der Chemotherapie: Nach 5 Jahren waren noch 67\% krankheitsfrei im Vergleich zu 35\% ohne zusätzliche Chemotherapie (HR 0,32; 95\%-KI 0,14-0,73; $\mathrm{p}=0,007$ ). In der Gruppe der Patientinnen mit einem hormonrezeptorpositiven Mammakarzinom bestand dieser klare Vorteil allerdings nicht (krankheitsfreies Überleben 70 vs. 69\%, HR 0,94, p=0,87; Gesamtüberleben). Das 5-Jahres-Gesamtüberleben der Patientinnen mit einem hormonrezeptornegativen lokalen/lokoregionären Rezidiv betrug 79 vs. $69 \%$ zugunsten der Patientinnen mit Chemotherapie (HR 0,43; 95\%-KI 0,15-1,24; p=0,12). Im hormorezeptorpositiven Kollektiv zeigte sich ein Unterschied im 5-Jahres-Gesamtüberleben von $94 \mathrm{zu} \mathrm{80 \%} \mathrm{-} \mathrm{dieses} \mathrm{jedoch} \mathrm{nicht} \mathrm{statistisch} \mathrm{signifikant} \mathrm{(HR} \mathrm{0,40,}$ 95\%-KI 0,12-1,28; p = 0,12). Die fehlenden Signifikanzen in den Subgruppen in Bezug auf das Gesamtüberleben lassen sich jedoch auch durch die kleinen Kollektivgrößen erklären.

Es ist davon auszugehen, dass diese neuen Erkenntnisse nicht nur die weiteren Therapieempfehlungen beeinflussen werden, sondern auch das praktische klinische Management.

Bei Vorliegen eines positiven HER2-Status wird in jedem Falle bei Trastuzumab-naiven Patientinnen der Einsatz von Trastuzumab bei resezierbarem Tumor empfohlen, wobei diese Empfehlungen lediglich aus den Erfahrungen und Studien in der metastasierten Situation extrapoliert wurden $[1,53]$. Wurde Trastuzumab bereits adjuvant verabreicht, relativiert sich auch diese Empfehlung. Ggf. werden hier zukünftig neue zielgerichtete Therapien, wie Pertuzumab, von Interesse sein. Eine klare Indikation, sowohl für eine Therapie mit Trastuzumab als auch eine Chemotherapie, bestehen für Patientinnen mit fortgeschrittenen, nicht resezierbaren Tumoren.

\section{Radiotherapie des lokalen/lokoregionären Rezidivs des Mammakarzinoms}

$\nabla$

Sofern im Rahmen der primären, zumeist multimodalen Therapie der Patientin keine Radiotherapie erfolgte, besteht im Falle eines lokalen/ lokoregionären Rezidivs die Indikation zur Radiotherapie. Dieses gilt sowohl für ein erneutes brusterhaltendes operatives Vorgehen als auch nach Mastektomie oder ein operativ entferntes regionales Lymphknotenrezidiv und erhöht die Chance auf Kuration. Erfolgte im Rahmen der multimodalen Primärtherapie eine Bestrahlungsbehandlung, ist bei einem Rezidiv in den bestrahlten Bereichen in der Regel keine Strahlentherapie mehr möglich. In solchen Fällen 


\section{Radiotherapy of Loco-Regional Recurrence of Breast Cancer $\nabla$}

If a patient did not have radiotherapy during primary, usually multimodal therapy, radiotherapy is indicated for loco-regional recurrence. This applies to patients undergoing repeat breastconserving surgery and to patients who have mastectomy or surgical resection for regional lymph node recurrence and improves the chances of curative surgery. If radiotherapy was included as part of primary multimodal treatment, radiotherapy should not be used to treat recurrence in the irradiated area. In these patients, low-dose repeat radiation therapy with hyperthermia may offer an effective option [85,90-95].

\section{For recurrence after mastectomy}

If primary therapy already included post-mastectomy radiation therapy (PMRT) of the chest wall, repeat small volume radiation therapy (usually electron radiotherapy) is indicated in patients with unfavourable risk factors after surgery for recurrence [9698], although this must be discussed individually for every patient as the associated complication rates are high.

\section{After repeat breast-conserving surgical therapy}

If radiotherapy is done after primary breast-conserving surgery, treatment of in-breast recurrence can consist of repeat local breast-conserving excision followed in individual cases by repeat external radiation therapy or interstitial brachytherapy applied locally to reduce the risk of re-recurrence and prevent salvage mastectomy. This approach does not appear to compromise survival compared to ablation but further prospective studies are required for confirmation [99-101].

\section{For local/regional inoperable recurrence}

Repeat radiation therapy with hyperthermia is recommended for patients with inoperable in-breast recurrence. This recommendation also applies even if mastectomy with radical resection of in-breast recurrence was not possible or if other unfavourable features are present, e.g. lymphangiosis cutis [85,90,92,93,95]. The significant improvement of local tumour control achieved by synchronous radiotherapy with hyperthermia compared to radiotherapy alone has been confirmed in six randomised studies $[91,94,98]$.

\section{Electrochemotherapy (ECT), a New Local Palliative Therapy}

Electrochemotherapy represents an innovative approach for the treatment of loco-regional recurrence in a palliative setting [102-105]. Palliative treatment consists of the administration of a low-dose cytostatic drug, usually bleomycin, administered at a dosage of $15 \mathrm{mg} / \mathrm{m}^{2}$ body surface area and the additional use of electroporation to increase the local effectiveness of the cytostatic drug. This causes no damage to healthy tissue, as it only temporarily increases the permeability of the cell to admit the locally applied cytostatic drug using a current pulse ( $\bullet$ Fig. 2 ). Depending on the extent of the surface treated using electroporation, clinical side effects can include transient reddening of the skin and, depending on the depth of treatment, fascicular twitching of muscle during the application followed by sore muscles post-therapy. Variously shaped electrodes and needle sizes are available for local treatment. stellt eine niedrig dosierte neuerliche Bestrahlung mit Hyperthermie eine aussichtsreiche Option dar [85,90-95].

\section{Rezidiv nach Mastektomie}

War bereits während der Primärtherapie eine Post-Mastektomie-Bestrahlung (PMRT) der Thoraxwand vorgenommen worden, ist bei Vorliegen ungünstiger Risikofaktoren nach Rezidivoperation eine erneute kleinvolumige Bestrahlung - zumeist unter Verwendung von Elektronen - indiziert [96-98], wobei dies bei gegebener hoher Komplikationsrate mit jeder Patientin individuell besprochen werden muss.

\section{Nach erneuter brusterhaltender operativer Therapie}

Nach erfolgter Strahlentherapie bei initialem brusterhaltenden Vorgehen können bei „In-Brust“-Rezidiven und nach erneuter lokaler Exzision unter Brusterhalt in Einzelfällen eine wiederholte externe Bestrahlung oder eine interstitielle lokale Brachytherapie zur Reduktion des Re-Rezidivrisikos und zur Vermeidung einer Salvage-Mastektomie erwogen werden. Ein solches Vorgehen scheint die Überlebenswahrscheinlichkeit gegenüber einem ablativen Vorgehen nicht $\mathrm{zu}$ kompromittieren, muss aber noch durch prospektive Studien abgesichert werden [99-101].

\section{Bei lokaler/regionaler Inoperabilität}

Im Falle eines inoperablen In-Brust-Rezidivs wird eine neuerliche Bestrahlung mit Hyperthermie empfohlen. Dieselbe Empfehlung gilt auch, wenn mit einer Mastektomie aufgrund eines Brustrezidivs der Tumor nicht radikal entfernt wurde oder wenn andere ungünstige Konstellationen, z.B. eine Lymphangiosis cutis, vorliegen [85, 90,92, 93,95]. Die signifikante Verbesserung der lokalen Tumorkontrolle durch eine synchrone Hyperthermie im Vergleich mit einer alleinigen Radiotherapie wurde in 6 randomisierten Studien nachgewiesen [91, 94,98].

\section{Neue Lokaltherapieverfahren in der Palliation, Elektrochemotherapie (ECT) $\nabla$}

Mit der Elektrochemotherapie steht ein innovatives Verfahren zur Behandlung eines lokalen/lokoregionären Rezidivs in der palliativen Situation zur Verfügung [102-105]. Die palliative Behandlung besteht aus der Verabreichung eines niedrig dosierten Zytostatikums, aktuell in der Regel Bleomycin, mit einer Dosierung von $15 \mathrm{mg} / \mathrm{m}^{2}$ Körperoberfläche und die zusätzliche Anwendung der Elektroporation in der Zielsetzung, die Wirksamkeit des Zytostatikums lokal zu erhöhen. Dabei wird gesundes Gewebe nicht geschädigt, sondern ausschließlich während eines Stromimpulses die Zellpermeabilität der Tumorzellen für das lokal verabreichte Zytostatikums erhöht ( $\bullet$ Abb. 2). Klinische Nebenwirkungen sind je nach Ausmaß der mittels Elektroporation behandelten Fläche eine vorübergehende Rötung der Haut und je nach Tiefe während der Behandlung auftretende Muskelfaszikulationen und posttherapeutisch Beschwerden analog eines Muskelkaters. Zur Verfügung stehen Elektroden in verschiedenen Formen und Nadelgrößen zur lokalen Behandlung.

\section{Fazit}

$\nabla$

Im Vergleich zu einer Fernmetastasierung besteht bei Patientinnen mit einem klinisch nachzuweisenden alleinigen lokalen/lokoregionären Rezidiv ein kurativer Ansatz, der ein individualisiertes und interdisziplinäres Vorgehen erfordert, bestehend aus operativer Therapie 


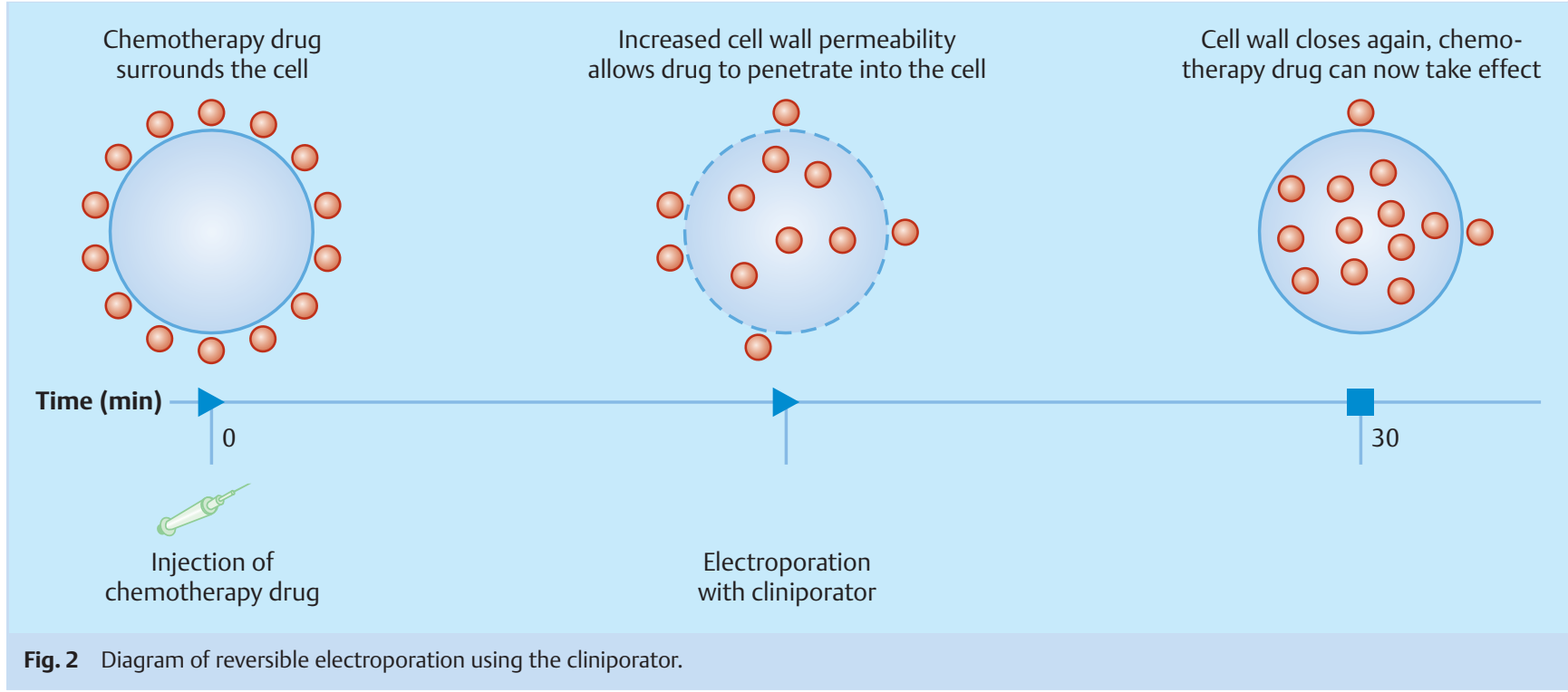

\section{Conclusion}

Compared to patients with distant metastasis, a curative approach is possible for patients with clinically proven isolated loco-regional recurrence. This requires an individualised and interdisciplinary strategy and includes surgical therapy with or without radiotherapy and/or systemic therapy. Treatment strategies must always be based on a treatment plan agreed upon in an interdisciplinary tumour conference.

The current therapy recommendations propose the use of endocrine systemic therapy to treat patients with hormone receptorpositive breast cancer. However, currently there are no such clear recommendations on chemotherapy for patients with hormone receptor-negative breast cancer. The current data of the CALOR trial challenge this and indicate that this must be reassessed. It can be safely assumed that the new findings will not only affect future therapy recommendations, they will also have an impact on the entire clinical management of isolated loco-regional recurrence of breast cancer.

\section{Conflict of Interest}

$\nabla$

None.

\section{References}

1 Interdisziplinäre S3-Leitlinie für die Diagnostik, Therapie und Nachsorge des Mammakarzinoms. Langversion 3.0, Aktualisierung 2012, AWMF-Register-Nummer: 032-045OL. http://www.dggg.de/ fileadmin/public_docs/Leitlinien/S3-Brustkrebs-v2012-OLLangversion.pdf; last access: 04/2013

2 Bruce J, Carter DC, Fraser J. Patterns of recurrent disease in breast cancer. Lancet 1970; 1: 433-435

3 Kurtz JM, Amalric R, Brandone $H$ et al. Local recurrence after breastconserving surgery and radiotherapy. Frequency, time course, and prognosis. Cancer 1989; 63: 1912-1917

4 Haffty BG, Fischer D, Beinfield $M$ et al. Prognosis following local recurrence in the conservatively treated breast cancer patient. Int J Radiat Oncol Biol Phys 1991; 21: 293-298

5 Reddy JP, Levy L, Oh JL et al. Long-term outcomes in patients with isolated supraclavicular nodal recurrence after mastectomy and doxorubicin-based chemotherapy for breast cancer. Int J Radiat Oncol Biol Phys 2011; 80: 1453-1457 mit oder ohne Strahlentherapie und/oder einer systemischen Therapie. Grundlage sollte immer eine Therapieplanung im Rahmen einer interdisziplinären Tumorkonferenz sein.

Neben den aktuellen Therapieempfehlungen, die für die Patientin mit einem hormonrezeptorpositiven Mammakarzinom eine endokrine systemische Therapie vorsehen, bestand für die Patientin mit einem hormonrezeptornegativem Mammakarzinom keine eindeutige Empfehlung zugunsten einer Chemotherapie. Aktuelle Daten der CALORStudie stellen dieses infrage bzw. regen dazu an, dieses kritisch zu überdenken. Es ist davon auszugehen, dass diese neuen Erkenntnisse nicht nur die weiteren Therapieempfehlungen beeinflussen werden, sondern auch das gesamte klinische Management des alleinigen lokalen bzw. lokoregionären Rezidivs.

\section{Interessenkonflikt \\ $\nabla$}

Nein.
6 Andersson Y, de Boniface J, Jonsson PE et al. Axillary recurrence rate 5 years after negative sentinel node biopsy for breast cancer. Br J Surg 2012; 99: 226-231

7 Karabali-Dalamaga S, Souhami RL, O'Higgins NJ et al. Natural history and prognosis of recurrent breast cancer. Br Med J 1978; 2: 730-733

8 Wapnir IL, Anderson SJ, Mamounas EP et al. Prognosis after ipsilateral breast tumor recurrence and locoregional recurrences in five National Surgical Adjuvant Breast and Bowel Project node-positive adjuvant breast cancer trials. J Clin Oncol 2006; 24: 2028-2037

9 Khatcheressian JL, Wolff AC, Smith TJ et al. American Society of Clinical Oncology 2006 update of the breast cancer follow-up and management guidelines in the adjuvant setting. J Clin Oncol 2006; 24: 50915097

10 Montgomery DA, Krupa K, Cooke TG. Follow-up in breast cancer: does routine clinical examination improve outcome? A systematic review of the literature. $\mathrm{Br} \mathrm{J}$ Cancer 2007; 97: 1632-1641 
11 Samant RS, Olivotto IA, Jackson JS et al. Diagnosis of metachronous contralateral breast cancer. Breast J 2001; 7: 405-410

12 Beinart G, Gonzalez-Angulo AM, Broglio K et al. Clinical course of 771 patients with bilateral breast cancer: characteristics associated with overall and recurrence-free survival. Clin Breast Cancer 2007; 7: 867874

13 Kollias J, Ellis IO, Elston CWet al. Prognostic significance of synchronous and metachronous bilateral breast cancer. World J Surg 2001; 25: 1117-1124

14 Mellink WA, Holland R, Hendriks JH et al. The contribution of routine follow-up mammography to an early detection of asynchronous contralateral breast cancer. Cancer 1991; 67: 1844-1848

15 Rosenow T, Biedendieck C, Fricke $H$ et al. Sentinel lymph node biopsy in patients with breast cancer: comparison of peritumoral and periareolar injection. Geburtsh Frauenheilk 2012; 72: 1024-1028

16 Wallgren A, Bonetti M, Gelber RD et al. Risk factors for locoregional recurrence among breast cancer patients: results from International Breast Cancer Study Group Trials I through VII. J Clin Oncol 2003; 21: 1205-1213

17 Fisher B, Anderson S, Bryant J et al. Twenty-year follow-up of a randomized trial comparing total mastectomy, lumpectomy, and lumpectomy plus irradiation for the treatment of invasive breast cancer. $\mathrm{N}$ Engl J Med 2002; 347: 1233-1241

18 Dalberg K, Mattsson A, Rutqvist LE et al. Breast conserving surgery for invasive breast cancer: risk factors for ipsilateral breast tumor recurrences. Breast Cancer Res Treat 1997; 43: 73-86

19 Truong PT, Yong CM, Abnousi F et al. Lymphovascular invasion is associated with reduced locoregional control and survival in women with node-negative breast cancer treated with mastectomy and systemic therapy. J Am Coll Surg 2005; 200: 912-921

20 Smith TE, Lee $D$, Turner $B C$ et al. True recurrence vs. new primary ipsilateral breast tumor relapse: an analysis of clinical and pathologic differences and their implications in natural history, prognoses, and therapeutic management. Int J Radiat Oncol Biol Phys 2000; 48: 12811289

21 Lowery AJ, Kell MR, Glynn RW et al. Locoregional recurrence after breast cancer surgery: a systematic review by receptor phenotype. Breast Cancer Res Treat 2012; 133: 831-841

22 Hunt KK, Ballman KV, McCall LM et al. Factors associated with local-regional recurrence after a negative sentinel node dissection: results of the ACOSOG Z0010 trial. Ann Surg 2012; 256: 428-436

23 van der Hage JA, Mieog JS, van de Velde CJ et al. Impact of established prognostic factors and molecular subtype in very young breast cancer patients: pooled analysis of four EORTC randomized controlled trials. Breast Cancer Res 2011; 13: R68

24 de Bock GH, van der Hage JA, Putter H et al. Isolated loco-regional recurrence of breast cancer is more common in young patients and following breast conserving therapy: long-term results of European Organisation for Research and Treatment of Cancer studies. Eur J Cancer 2006; 42: 351-356

25 Jobsen JJ, van der Palen J, Meerwaldt JH. The impact of age on local control in women with pT1 breast cancer treated with conservative surgery and radiation therapy. Eur J Cancer 2001; 37: 1820-1827

26 Clarke M, Collins R, Darby S et al. Effects of radiotherapy and of differences in the extent of surgery for early breast cancer on local recurrence and 15-year survival: an overview of the randomised trials. Lancet 2005; 366: 2087-2106

27 Cheng SH, Horng CF, Clarke JL et al. Prognostic index score and clinical prediction model of local regional recurrence after mastectomy in breast cancer patients. Int J Radiat Oncol Biol Phys 2006; 64: 14011409

28 Knauerhase H, Strietzel M, Gerber B et al. Tumor location, interval between surgery and radiotherapy, and boost technique influence local control after breast-conserving surgery and radiation: retrospective analysis of monoinstitutional long-term results. Int J Radiat Oncol Biol Phys 2008; 72: 1048-1055

29 Voduc KD, Cheang MC, Tyldesley S et al. Breast cancer subtypes and the risk of local and regional relapse. J Clin Oncol 2010; 28: 1684-1691

30 Rauh C, Hack CC, Häberle L et al. Percent mammographic density and dense area as risk factors for breast cancer. Geburtsh Frauenheilk 2012; 72: 727-733

31 Halverson KJ, Perez CA, Kuske RR et al. Survival following locoregional recurrence of breast cancer: univariate and multivariate analysis. Int J Radiat Oncol Biol Phys 1992; 23: 285-291
32 Katz A, Strom EA, Buchholz TA et al. The influence of pathologic tumor characteristics on locoregional recurrence rates following mastectomy. Int J Radiat Oncol Biol Phys 2001; 50: 735-742

33 van Tienhoven G, Voogd AC, Peterse JL et al. Prognosis after treatment for loco-regional recurrence after mastectomy or breast conserving therapy in two randomised trials (EORTC10801 and DBCG-82 TM). EORTC Breast Cancer Cooperative Group and the Danish Breast Cancer Cooperative Group. Eur J Cancer 1999; 35: 32-38

34 Lannin DR, Haffty BG. End results of salvage therapy after failure of breast-conservation surgery. Oncology (Williston Park) 2004; 18 : 272-279; discussion 280-282, 285-286, 292

35 Panet-Raymond V, Truong PT, Alexander C et al. Clinicopathologic factors of the recurrent tumor predict outcome in patients with ipsilateral breast tumor recurrence. Cancer 2011; 117: 2035-2043

36 Clemons M, Hamilton T, Goss P. Does treatment at the time of locoregional failure of breast cancer alter prognosis? Cancer Treat Rev 2001; 27: 83-97

37 Haffty BG, Reiss $M$, Beinfield $M$ et al. Ipsilateral breast tumor recurrence as a predictor of distant disease: implications for systemic therapy at the time of local relapse. J Clin Oncol 1996; 14: 52-57

38 Kuo SH, Huang CS, Kuo WH et al. Comprehensive locoregional treatment and systemic therapy for postmastectomy isolated locoregional recurrence. Int J Radiat Oncol Biol Phys 2008; 72: 1456-1464

39 Lee JS, Kim SI, Park HS et al. The impact of local and regional recurrence on distant metastasis and survival in patients treated with breast conservation therapy. J Breast Cancer 2011; 14: 191-197

40 Huang E, Buchholz TA, Meric $F$ et al. Classifying local disease recurrences after breast conservation therapy based on location and histology: new primary tumors have more favorable outcomes than true local disease recurrences. Cancer 2002; 95: 2059-2067

41 Panet-Raymond V, Truong PT, McDonald RE et al. True recurrence versus new primary: an analysis of ipsilateral breast tumor recurrences after breast-conserving therapy. Int J Radiat Oncol Biol Phys 2011; 81: 409417

42 Schwaibold F, Fowble BL, Solin $L J$ et al. The results of radiation therapy for isolated local regional recurrence after mastectomy. Int J Radiat Oncol Biol Phys 1991; 21: 299-310

43 Borner M, Bacchi M, Goldhirsch A et al. First isolated locoregional recurrence following mastectomy for breast cancer: results of a phase III multicenter study comparing systemic treatment with observation after excision and radiation. Swiss Group for Clinical Cancer Research. J Clin Oncol 1994; 12: 2071-2077

44 Haylock BJ, Coppin CM, Jackson J et al. Locoregional first recurrence after mastectomy: prospective cohort studies with and without immediate chemotherapy. Int J Radiat Oncol Biol Phys 2000; 46: 355-362

45 Easson AM, McCready DR. Management of local recurrence of breast cancer. Expert Rev Anticancer Ther 2004; 4: 219-226

46 Lüftner D, Lux MP, Maass $N$ et al. Advances in breast cancer - looking back over the year. Geburtsh Frauenheilk 2012; 72: 1117-1129

47 Kolberg H-C, Lüftner D, Lux MP et al. Breast cancer 2012 - new aspects. Geburtsh Frauenheilk 2012; 72: 602-615

48 Alpert TE, Kuerer HM, Arthur DW et al. Ipsilateral breast tumor recurrence after breast conservation therapy: outcomes of salvage mastectomy vs. salvage breast-conserving surgery and prognostic factors for salvage breast preservation. Int J Radiat Oncol Biol Phys 2005; 63: 845851

49 Komoike Y, Akiyama F, Iino Y et al. Analysis of ipsilateral breast tumor recurrences after breast-conserving treatment based on the classification of true recurrences and new primary tumors. Breast Cancer 2005; 12: $104-111$

50 Buchanan CL, Dorn PL, Fey J et al. Locoregional recurrence after mastectomy: incidence and outcomes. J Am Coll Surg 2006; 203: 469-474

51 Taylor ME, Perez CA, Halverson KJ et al. Factors influencing cosmetic results after conservation therapy for breast cancer. Int J Radiat Oncol Biol Phys 1995; 31: 753-764

52 van der Pol CC, van Geel AN, Menke-Pluymers MB et al. Prognostic factors in 77 curative chest wall resections for isolated breast cancer recurrence. Ann Surg Oncol 2009; 16: 3414-3421

53 Cardoso F, Harbeck N, Fallowfield L et al. Locally recurrent or metastatic breast cancer: ESMO Clinical Practice Guidelines for diagnosis, treatment and follow-up. Ann Oncol 2012; 23 (Suppl. 7): vii11-vii19

54 Hammond ME, Hayes DF, Dowsett $M$ et al. American Society of Clinical Oncology/College Of American Pathologists guideline recommendations for immunohistochemical testing of estrogen and progesterone receptors in breast cancer. J Clin Oncol 2010; 28: 2784-2795 
55 Wolff AC, Hammond ME, Schwartz JN et al. American Society of Clinical Oncology/College of American Pathologists guideline recommendations for human epidermal growth factor receptor 2 testing in breast cancer. J Clin Oncol 2007; 25: 118-145

56 Jabbour MN, Massad CY, Boulos FI. Variability in hormone and growth factor receptor expression in primary versus recurrent, metastatic, and post-neoadjuvant breast carcinoma. Breast Cancer Res Treat 2012; 135: 29-37

57 Bogina G, Bortesi L, Marconi M et al. Comparison of hormonal receptor and HER-2 status between breast primary tumours and relapsing tumours: clinical implications of progesterone receptor loss. Virchows Arch 2011; 459: 1-10

58 Gomez-Fernandez C, Daneshbod Y, Nassiri M et al. Immunohistochemically determined estrogen receptor phenotype remains stable in recurrent and metastatic breast cancer. Am J Clin Pathol 2008; 130: 879-882

59 Guarneri V, Giovannelli S, Ficarra G et al. Comparison of HER-2 and hormone receptor expression in primary breast cancers and asynchronous paired metastases: impact on patient management. Oncologist 2008; 13: 838-844

60 Hahnel R, Twaddle E. The relationship between estrogen receptors in primary and secondary breast carcinomas and in sequential primary breast carcinomas. Breast Cancer Res Treat 1985; 5: 155-163

61 Idirisinghe PK, Thike AA, Cheok PY et al. Hormone receptor and c-ERBB2 status in distant metastatic and locally recurrent breast cancer. Pathologic correlations and clinical significance. Am J Clin Pathol 2010; 133: 416-429

62 Lower EE, Glass EL, Bradley DA et al. Impact of metastatic estrogen receptor and progesterone receptor status on survival. Breast Cancer Res Treatment 2005; 90: 65-70

63 Rosen PP, Menendez-Botet CJ, Urban JA et al. Estrogen receptor protein (ERP) in multiple tumor specimens from individual patients with breast cancer. Cancer 1977; 39: 2194-2200

64 Shimizu C, Fukutomi T, Tsuda H et al. c-erbB-2 protein overexpression and p53 immunoreaction in primary and recurrent breast cancer tissues. J Surg Oncol 2000; 73: 17-20

65 Veronesi U, Marubini E, Del Vecchio $M$ et al. Local recurrences and distant metastases after conservative breast cancer treatments: partly independent events. J Natl Cancer Inst 1995; 87: 19-27

66 Veronesi U, Marubini E, Mariani L et al. Radiotherapy after breast-conserving surgery in small breast carcinoma: long-term results of a randomized trial. Ann Oncol 2001; 12: 997-1003

67 Liljegren G, Holmberg L, Bergh J et al. 10-Year results after sector resection with or without postoperative radiotherapy for stage I breast cancer: a randomized trial. J Clin Oncol 1999; 17: 2326-2333

68 Clark RM, Whelan T, Levine $M$ et al. Randomized clinical trial of breast irradiation following lumpectomy and axillary dissection for nodenegative breast cancer: an update. Ontario Clinical Oncology Group. J Natl Cancer Inst 1996; 88: 1659-1664

69 Haffty BG, Carter D, Flynn SD et al. Local recurrence versus new primary: clinical analysis of 82 breast relapses and potential applications for genetic fingerprinting. Int J Radiat Oncol Biol Phys 1993; 27: 575583

70 Krauss DJ, Kestin LL, Mitchell C et al. Changes in temporal patterns of local failure after breast-conserving therapy and their prognostic implications. Int J Radiat Oncol Biol Phys 2004; 60: 731-740

71 Freedman GM, Anderson PR, Hanlon AL et al. Pattern of local recurrence after conservative surgery and whole-breast irradiation. Int J Radiat Oncol Biol Phys 2005; 61: 1328-1336

72 Nishimura S, Takahashi K, Akiyama F et al. Classification of ipsilateral breast tumor recurrence after breast-conserving therapy: new primary cancer allows a good prognosis. Breast Cancer 2005; 12: 112-117

73 Schmidt M, Fasching PA, Beckmann MW et al. Biomarkers in breast cancer - an update. Geburtsh Frauenheilk 2012; 72: 819-832

74 Alkner S, Bendahl PO, Ferno M et al. Prediction of outcome after diagnosis of metachronous contralateral breast cancer. BMC Cancer 2011; 11: 114

75 Banelli B, Casciano I, Di Vinci A et al. Pathological and molecular characteristics distinguishing contralateral metastatic from new primary breast cancer. Ann Oncol 2010; 21: 1237-1242

76 Reding KW, Bernstein JL, Langholz BM et al. Adjuvant systemic therapy for breast cancer in BRCA1/BRCA2 mutation carriers in a populationbased study of risk of contralateral breast cancer. Breast Cancer Res Treat 2010; 123: 491-498
77 Rhiem KP, Pfeifer K, Schmutzler RK et al. Risk-reducing surgery in women at risk for familial breast or ovarian cancer. Geburtsh Frauenheilk 2012; 72: 833-839

78 Vichapat V, Garmo H, Holmberg L et al. Prognosis of metachronous contralateral breast cancer: importance of stage, age and interval time between the two diagnoses. Breast Cancer Res Treat 2011; 130: 609-618

79 Burns PE, Dabbs K, May C et al. Bilateral breast cancer in northern Alberta: risk factors and survival patterns. Can Med Assoc J 1984; 130 : 881-886

80 Kurian AW, McClure LA, John EM et al. Second primary breast cancer occurrence according to hormone receptor status. J Natl Cancer Inst 2009; 101: 1058-1065

81 Houssami N, Ciatto S, Martinelli F et al. Early detection of second breast cancers improves prognosis in breast cancer survivors. Ann Oncol 2009; 20: 1505-1510

82 Vichapat V, Gillett C, Fentiman IS et al. Risk factors for metachronous contralateral breast cancer suggest two aetiological pathways. Eur J Cancer 2011; 47: 1919-1927

83 Le MG, Arriagada R, Spielmann M et al. Prognostic factors for death after an isolated local recurrence in patients with early-stage breast carcinoma. Cancer 2002; 94: 2813-2820

84 Halverson KJ, Perez CA, Kuske RR et al. Locoregional recurrence of breast cancer: a retrospective comparison of irradiation alone versus irradiation and systemic therapy. Am J Clin Oncol 1992; 15: 93-101

85 NCCN (National Comprehensive Cancer Network, 2012). http://www. nccn.org/professionals/physician_gls/PDF/breast.pdf; last access: 13.01.2013

86 Rauschecker H, Clarke M, Gatzemeier W et al. Systemic therapy for treating locoregional recurrence in women with breast cancer. Cochrane Database Syst Rev 2001; 4: CD002195

87 Wapnir IL, Aebi S, Gelber S et al. Progress on BIG 1-02/IBCSG 27-02 NSABP B-37, a prospective randomized trial evaluating chemotherapy after local therapy for isolated locoregional recurrences of breast cancer. Ann Surg Oncol 2008; 15: 3227-3231

88 Tokunaga Y, Hosogi H, Nakagami M et al. A case of chest wall recurrence of breast cancer treated with paclitaxel weekly, 5'-deoxy-5-fluorouridine, arterial embolization and chest wall resection. Breast Cancer 2003; 10: 366-370

89 Aebi SG, Gelber S, Láng I et al. Chemotherapy prolongs survival for isolated local or regional recurrence of breast cancer: the CALOR trial (Chemotherapy as adjuvant for locally recurrent breast cancer; IBCSG 27-02, NSABP B-37, BIG 1-02). Cancer Res 2012; 72 (24 Suppl.): Abstr. $96 \mathrm{~s}$

90 Hehr T, Lamprecht $U$, Glocker S et al. Thermoradiotherapy for locally recurrent breast cancer with skin involvement. Int J Hyperthermia 2001; 17: 291-301

91 Jones EL, Oleson JR, Prosnitz LR et al. Randomized trial of hyperthermia and radiation for superficial tumors. J Clin Oncol 2005; 23: 3079-3085

92 Kapp DS, Cox RS, Barnett TA et al. Thermoradiotherapy for residual microscopic cancer: elective or post-excisional hyperthermia and radiation therapy in the management of local-regional recurrent breast cancer. Int J Radiat Oncol Biol Phys 1992; 24: 261-277

93 van der Zee J, van Rhoon GC, Wijnmaalen AJ et al. [Re-irradiation with hyperthermia in patients with recurrent breast cancer]. Nederlands tijdschrift voor geneeskunde 1999; 143: 80-84

94 Vernon CC, Hand JW, Field SB et al. Radiotherapy with or without hyperthermia in the treatment of superficial localized breast cancer: results from five randomized controlled trials. International Collaborative Hyperthermia Group. Int J Radiat Oncol Biol Phys 1996; 35: 731744

95 Wahl AO, Rademaker A, Kiel KD et al. Multi-institutional review of repeat irradiation of chest wall and breast for recurrent breast cancer. Int J Radiat Oncol Biol Phys 2008; 70: 477-484

96 Aberizk WJ, Silver B, Henderson IC et al. The use of radiotherapy for treatment of isolated locoregional recurrence of breast carcinoma after mastectomy. Cancer 1986; 58: 1214-1218

97 van Dongen JA, Bartelink H, Fentiman IS et al. Factors influencing local relapse and survival and results of salvage treatment after breast-conserving therapy in operable breast cancer: EORTC trial 10801, breast conservation compared with mastectomy in TNM stage I and II breast cancer. Eur J Cancer 1992; 28 A: 801-805

98 Zagar TM, Higgins KA, Miles EF et al. Durable palliation of breast cancer chest wall recurrence with radiation therapy, hyperthermia, and chemotherapy. Radiother Oncol 2010; 97: 535-540 
99 Deutsch $M$. Repeat high-dose external beam irradiation for in-breast tumor recurrence after previous lumpectomy and whole breast irradiation. Int J Radiat Oncol Biol Phys 2002; 53: 687-691

100 Newman LA, Kuerer HM. Advances in breast conservation therapy. J Clin Oncol 2005; 23: 1685-1697

101 Resch A, Fellner C, Mock U et al. Locally recurrent breast cancer: pulse dose rate brachytherapy for repeat irradiation following lumpectomy - a second chance to preserve the breast. Radiology 2002; 225: 713718

102 Benevento R, Santoriello A, Perna G et al. Electrochemotherapy of cutaneous metastastes from breast cancer in elderly patients: a preliminary report. BMC Surg 2012; 12 (Suppl. 1): S6
103 Sersa G, Cufer T, Paulin SM et al. Electrochemotherapy of chest wall breast cancer recurrence. Cancer Treat Rev 2012; 38: 379-386

104 Campana LG, Valpione S, Falci C et al. The activity and safety of electrochemotherapy in persistent chest wall recurrence from breast cancer after mastectomy: a phase-II study. Breast Cancer Res Treat 2012; 134: $1169-1178$

105 Matthiessen LW, Johannesen HH, Hendel HW et al. Electrochemotherapy for large cutaneous recurrence of breast cancer: a phase II clinical trial. Acta Oncol 2012; 51: 713-721

Deutschsprachige Zusatzinformationen online abrufbar unter: www.thieme-connect.de/ejournals/toc/gebfra. 